\title{
The Empirical Study on the Relationship of IPO Lockup, Earnings Management and Venture Capital
}

\author{
Lan Zhou \\ South China University of Technology, Guangzhou, China \\ Email: zhou_lan@foxmail.com
}

How to cite this paper: Zhou, L. (2017) The Empirical Study on the Relationship of IPO Lockup, Earnings Management and Venture Capital. Modern Economy, 8, 1082-1097.

https://doi.org/10.4236/me.2017.89075

Received: July 21, 2017

Accepted: August 27, 2017

Published: August 30, 2017

Copyright $\odot 2017$ by author and Scientific Research Publishing Inc. This work is licensed under the Creative Commons Attribution International License (CC BY 4.0).

http://creativecommons.org/licenses/by/4.0/

\section{(c) (i) Open Access}

\begin{abstract}
Earnings management occurs when management's autonomy allows managers to change the surpluses and then mislead investors about potential company's performance and quality. According to the sample of 330 listed companies on the GEM, we use the event study and modified Jones model to measure variables and then find that the market investors can guard against the earnings management behavior by observing the abnormal reverse volatility of the IPO stock lifting period, which can be looked as a negative signal. In addition, the study also finds that the IPO firms supported by venture capital institutions have stronger earnings management at the lockup expiration period. Moreover, the state-owned background and high reputation of venture capital institutions has negative regulation function, which can supervise and audit the earnings management behavior of enterprises after IPO, thus weakening the negative volatility of the market. From the point of view of signal theory, this paper probes into the negative signals of earnings management behavior of IPO during the lockup expiration period, and has a better understanding of the transfer of negative signals.
\end{abstract}

\section{Keywords}

Earnings Management, IPO Lockup, Venture Capitalists, Signal Theory

\section{Introduction}

Initial public offering (IPO) is a type of public offering in which shares of a company usually are sold to institutional investors that in turn, sell to the general public, on a securities exchange, for the first time. The high degree of asymmetric information between internal and external investors is a prominent feature 
of IPO enterprises, so external investors are faced with various difficulties in assessing the true value of enterprises in IPO. Even after IPO, it is difficult for external investors to judge existing performance through limited financial data [1], which is called earnings management. Earnings management involves the alteration of financial reports to mislead stakeholders about the organization's underlying performance, or to "influence contractual outcomes that depend on reported accounting numbers." This has led to the opportunity for insiders to drive short-term stock prices by manipulating financial information [2]. Outside investors, however, are unable to observe this behavior and need to be tested by certain signals. Therefore, this paper is based on the signal theory, as a negative signal to the abnormal fluctuation of stock lifted by IPO negative, distinguishing enterprise is the existence of earnings management, and the introduction of risk investment institutions, explore the relationship between the three.

Although signal theory has been widely used in the study of IPO process, there are still three aspects to be further explored. First of all, little attention has been paid to the transmission of passive signals in signal theory research [3]. At present, the discussion of signal transmission is mainly focused on the impact of positive signals, while the research on the judgment and detection of negative signals released by IPO enterprises is less. Second, the former signal theory regards the enterprise as a whole and studies how the investors benefit from the signals sent by the enterprise. However, in real life, enterprises are often multiple interest groups coexist in the organization, because of agency problems, conflicts and contradictions within the organization of different interest groups will affect the enterprise profit allocation results, and thus have an impact on the external market. Therefore, it is very important to understand how the internal stakeholders in IPO enterprises influence corporate behavior and what kind of signal transmission it causes. Finally, signal theory pays little attention to the study of signal reception [3]. The receiver can alter the effect of signal transmission by rewarding or punishing the sender, so it is important to study how the receiver identifies and reacts.

In view of this, based on China's GEM market from 2009 to 2016 IPO company as the research object, this article studies the following problems: the lifting of the ban period, the stock price of IPO enterprise negative abnormal fluctuations can be seen as a negative signal of enterprise earnings management? What are the roles of venture capital? What impact does the background and reputation have on the performance of the signal? The study found: first, IPO shares price showed negative abnormal fluctuations to some extent explain the impact that enterprises do on the market by positive earnings management behavior after lockup expiration; second, the relationship between negative abnormal fluctuation and earnings management will be more closely linked in the enterprises that venture backed on lockup period; third, positive association between the presence of $V C s$ and earnings management behavior is attenuated when the $V C s$ are non-government background; fourth, positive association between the presence of $V C s$ and earnings management behavior is attenuated when the VCs 
are highly reputable. Overall, after IPO lockup expiration, the negative abnormal returns to the corporate earnings management behavior and market performance, the heterogeneity of risk investment institutions to support both reflect the relationship play a regulatory role, namely, different types of $V C s$ in a certain extent affected the reaction degree of the market on earnings management behavior of enterprises.

The other parts of this paper are as follows: the second part is the literature review and research hypothesis; the third part is the data source and research design; the fourth part is the empirical results and analysis; the fifth part is the conclusion of the study.

\section{Background}

\subsection{Earnings Management and IPO Lockup}

Defined by the securities law, IPO lockup means the company's shares on the stock exchange date shall not be transferred within a certain period of time, before the lockup, before listing shareholders can freely sell their shares. Therefore, the IPO lockup has become an original shareholder of the enterprise, such as the risk of institutional investors out of an important signal. Before the initial release of the original shares, the only financial report disclosed by the enterprise was an important basis for investors to judge the value of the company [4]. Because of the imperfection and flexibility of the accounting system, the management and the shareholders have considerable discretion in the recognition of income and expenditure. Healy and Wahlen (1999) put forward the concept of behavior motivation of earnings management according to the different behavior motivation [5]. The earnings management of capital market motivation based on pointed out that due to the company to realize the accounting information and the earnings information will be used for the majority of investors to determine the operation of the company, estimates the value of the stock and on this basis, so the internal people probably through positive earnings manipulation to influence investor to judge the effect of stock price.

At the same time, earnings management also has negative consequences, such as litigation costs, reputation losses, loss of future accounting flexibility and negative long-term returns. When investors find that any information in the invested enterprise is untrue or missing, it is very likely to lead to "voting with their feet" or even bringing a lawsuit. The potential costs of litigation and related reputational losses can sometimes even threaten enterprise survival [1]. In addition, the problem of earnings management of enterprises may also reduce the flexibility of accounting in the future, when managers exaggerated income, they will have less financial freedom in the subsequent time and ultimately have a negative impact on enterprises. As a result, as time passes, more accurate information spreads, market will reduce the valuations of earnings management companies. Therefore, firms with high levels of earnings management tend to exhibit serious negative long-term stock returns. 


\subsection{Signal Transmission between Earnings Management and Stock Price Effect}

The theory of signal transmission is based on the Asymmetric Information theory, which firstly put forward by Pettit (1972) is based on the study of the market response of dividend information. Signal theory that the signal sender with its behavior intention of information processing, and the receiver according to the charge signal in accordance with their own interpretation of decisions [6]. Previous studies mostly started from the point of view of positive signals, which means that signals play an active role in the transmission process. For example, if the managers hold company's shares for a long time, it transfer its positive signal with high quality [7], the receiver can signal through the signal selection of holdings of shares in the company to make a profit. The difference between a negative signal and a positive signal is whether the sender will lose the interest of an interest in the organization or other stakeholders in the market through the transmission of signals. Previous studies show that, when the retention of negative information will damage their own interests or the sender in the face of this kind of news is not as will be more punishment than a message, the sender signal will be forced to send negative signals [8] [9] [10].

In the context of this study, the lockup expiration is enterprise managers and shareholders to make the new enterprises more attractive in the deadline. The actions taken by companies in lockup expiration would distinguish them from companies that did not manage earnings. A good corporate whose shareholders in the lockup expiration will not be eager to cash in, on the contrary, corporates with earnings management shareholders will have stronger incentives to sell their shares, because they understand that their stocks are overvalued, when the market realizes, stock prices will likely decline rapidly [8]. Therefore, the enterprise staffs sell out amount of stocks after the lockup expiration, which makes damage to other stakeholders in this process, it can be called a negative signal, negative emotion and negative abnormal stock returns can be interpreted as the market towards the earnings management.

If managers manipulate earnings through the adjustment of accounting information, the stock price will achieve a significant increase in the short term, and external investors are likely to be deceived by the company's exaggerated performance for the time being. The original shareholders use their information advantage to earn excess investment premium, because they can't keep the longterm high attraction, therefore, when the stock out of lockup the original shareholders have the option of selling out the stock at inflated prices. This massive sell-off will lead to external investor concerns, and infer whether there retain some negative news that has not yet been found. The market will think this is a negative signal to sell. Therefore, this paper predicts that there is a positive correlation between the abnormal return and earnings management behavior during the lockup expiration.

Hypothesis 1: Negative abnormal returns at lockup expiration will be positively 
associated with levels of earnings management behavior.

\subsection{Involvement of Venture Capitalists}

In recent years, the rapid development of venture capital, especially with the rise of the GEM, the role of venture capital institutions in the process of IPO has attracted the attention of many scholars at home and abroad. The VCs not only give the financial support, but also support certain investment services, including strategic management, financial support, help enterprises to attain the growth of value [5] [7] [9]. But as yet, the academic community has not yet reached a coherent conclusion about whether venture capital institutions will influence the financial reporting information of the invested enterprises [9].

The investment cycle of $V C s$ can be divided into three phases: selectionnurturing, monitoring, and exit [11]. According to the time point of exit, venture capital institutions can be divided into immediate exit and long-term involvement. For long-term involvement of venture capital, it is often optimistic about the investment companies, through the assistance of enterprise management, in order to achieve long-term stock price appreciation, so as to achieve profitability. The immediate exit venture is aimed at the rapid withdrawal of the companies after the lockup, thus obtaining a high return on investment for investors of $V C s$ in a short period of time. Therefore, long-term holding VCs have a long-term plan for the enterprise and the lower possibility of the existence of earnings management behavior than the immediate exit $V C s$ which have a greater incentive to manage earnings in the period before lockup in order to improve the stock price.

The VCs is important IPO shareholders and also is venture capital fund managers. This dual identity will inevitably lead to the problem of distribution of interests between different positions [10] [11] [12]. Although shareholders are generally considered to be long-term holders of enterprises, but between an enterprise of different shareholders have different investment objectives and plans, thus it is difficult to avoid interest conflict [13]. Chahine, et al. (2012) found that because of the conflict of objectives, the diversity of IPO shareholders is more likely to lead to negative results such as earnings management [14].

First, venture capitalists face huge time pressures in their investments. Early withdrawal can reduce volatility due to related risk caused by external environment factors or invested, and quickly obtain early gains from the IPO to help make up for the other investment losses. In addition, although long-term investment can increase enterprise value and increase the return of investment, it also means higher cost of opportunity. Secondly, after the IPO, venture capital institutions' control gradually weakened, and the impact on enterprise managers was reduced. Therefore, realized investment income is more attractive than continued participation in management. Before IPO, VCs are often involved in business management as a strategic investor, so it can gain control over ordinary shareholders, but after IPO venture capital institutions shares change into ordinary shares, and shares being diluted, and the actual control is weakened, and 
venture capital institutions often turning into financial investors tend to sell at a profit. Therefore, this paper argues that venture capital institutions have more incentive and pressure as fund managers than enterprise shareholders, and venture capital institutions under this pressure will promote earnings management. Therefore, firms with venture capital institutions are more likely to generate earnings management than firms without venture capital support.

Hypothesis 2: IPO firms backed by venture capitalists will be associated with higher levels of earnings management behavior.

\subsection{Moderating Role of VC State-Own Background and Reputation}

The characteristics of venture capital will also affect its role in the invested enterprises. First of all, the background of venture capital institutions will affect the abnormal volatility of the market and the relationship between the earnings management behavior of enterprises. Venture capital institutions with stateowned background have obvious resource advantages in political connections. SOE background will help $V C$ in the IPO application process and establish direct dialogue mechanism with regulatory authorities, access to important information, and may even bring some policy tilt. Therefore, venture investment institutions with state-owned background, on the one hand, to promote IPO will be more likely to allow the earnings management behavior of enterprises; on the other hand, between the venture capital institutions and political connections bring specific regulatory departments, will also bring information quality deregulation expectations for venture capital institutions. Therefore, in order to successfully promote IPO, VCs with state-owned enterprises background may have greater motivation to earnings management in IPO.

Secondly, the reputation of venture capital institutions has a greater impact on the behavior before the lockup. The more firms that $V C s$ foster and assist successfully, the higher their reputation is [4]. However, reputation is not simply based on a single and short-lived success. Successful nurturing of good companies and achieving many successes can ensure the reputation of venture capitalists. By this definition, firms with higher reputations are more likely to focus on the long-term success of the firms they invest in because their achievements can benefit their subsequent investment negotiations and work. According to existing research, VCs are more willing to accept higher reputation venture capital investment, and even willing to lower their investment valuation of $10 \%-14 \%$ [7].

Then, the higher the reputation, the more enterprises can monitor and prevent the earnings management behavior of enterprises. The reputation make this type of venture capital institutions to be able to mobilize more resources, so as to effectively intervene in the decision-making of enterprises, including strategic planning, financial management, operation management [7] [9]. The participation of these venture capital institutions gives them more opportunities to play the audit and regulatory functions, and more able to curb earnings management activities, thereby maintaining their reputation. In addition, earnings manage- 
ment is a kind of covert behavior, and its monitoring needs a certain amount of experience. Therefore, the venture capital institutions with higher industry status often have rich experience and can monitor the earnings management motivation and behavior within the enterprise.

Finally, the cost of the earnings management is greater for the reputation of venture capital, mainly due to its reputation creates revenue is far higher than the short-term effect of earnings management which has created, so in order to maintain this kind of income, venture capital institutions have enough motivation to supervise any potential earnings management in order to protect their reputation behavior. Based on these factors, it is assumed that the earnings management behavior is more likely to occur during the lockup expiration.

Hypothesis 3a: The association between negative abnormal returns at lockup expiration and earnings management behavior will be weaker with the presence of state-owned venture capitalists in the IPO process.

Hypothesis 3b: The association between negative abnormal returns at lockup expiration and earnings management behavior will be weaker with the presence of reputable venture capitalists in the IPO process.

\section{Method}

\subsection{Data and Sample}

The study takes the listed companies in China's growth enterprise market from 2009 to 2016 as the research object, and the data sources are the CSMAR financial research database. CSMAR database is the first and largest engaged in design and development of economic information database, is China data providers that is only brought into the service system of Walton by the Walton School of business in the Greater China region. During this period, there are 494 companies going public. Excluding financial data before and after issue, market transactions data inequality, the study sample is 330 companies. To confirm the risk investment background of listed companies, the author uses the manual through Sample Firms prospectus, in section "Five, the basic situation of the issuer -Six, the capital of the issuer" disclosed in the listing of the top ten shareholders shall prevail. In data processing, this paper generalized definition of risk investment institutions, doesn't make strict distinction of venture capital and private equity investment, for equity investment in non-listed enterprises of each stage will be identified as the mechanism of risk investment. Is recognized as risk investment institutions according to the "main business and business activities of the agency in the disclosure of the prospectus", such as the business scope includes venture capital, technology investment and other key to be identified as risk investment institutions, if the scope of business involves foreign investment, but did not specify the risk investment risk investment venture investment, investment, innovation, science and technology investment, through the Internet search company homepage or Zero 2IPO database to determine. If they are still unable to determine, they are define as non-risk investment institutions. In addition, the 
institution should not be related to the actual controller of the listed company, and is not the main shareholder of the employee as the main shareholder. The institution's investment time is not the same as the establishment of the enterprise, and have the relevant venture investment project experience, so that they can be identified as venture capital institutions. Finally, the 330 Sample Firms, identified 216 companies have venture background, accounting for $65.45 \%$ of the total sample.

\subsection{Dependent Variable}

Research and design of the model (1), model (2), model (3), model (4), respectively test $\mathrm{H} 1, \mathrm{H} 2, \mathrm{H} 3 \mathrm{a}, \mathrm{H} 3 \mathrm{~b}$ :

$$
\begin{aligned}
& D_{A C C_{i, t}=\alpha_{0}}+\alpha_{1} * \text { Age }+\alpha_{2} * \text { Growth }+\alpha_{3} * \text { Size }+\alpha_{4} T L U+\alpha_{5} C P A+\varepsilon \\
& D A C C_{i, t}= \alpha_{0}+\alpha_{1} * \text { Age }+\alpha_{2} * \text { Growth }+\alpha_{3} * \text { Size }+\alpha_{4} T L U+\alpha_{5} C P A \\
&+\alpha_{6} * C A R_{i, t}^{\prime}+\alpha_{7} * V C+\alpha_{8} C A R_{i, t}^{\prime} * V C+\varepsilon \\
& D A C C_{i, t}= \alpha_{0}+\alpha_{1} * \text { Age }+\alpha_{2} * \text { Growth }+\alpha_{3} * \text { Size }+\alpha_{4} T L U+\alpha_{5} C P A \\
&+\alpha_{6} * C A R_{i, t}^{\prime}+\alpha_{9} * V C_{b g}+\alpha_{10} C A R_{i, t}^{\prime} * V C_{b g}+\varepsilon \\
& D A C C_{i, t}= \alpha_{0}+\alpha_{1} * \text { Age }+\alpha_{2} * \text { Growth }+\alpha_{3} * \text { Size }+\alpha_{4} T L U+\alpha_{5} C P A \\
&+\alpha_{6} * C A R_{i, t}^{\prime}+\alpha_{11} * V C_{r p}+\alpha_{12} C A R_{i, t}^{\prime} * V C_{r p}+\varepsilon
\end{aligned}
$$

\subsection{Explained Variable}

The explained variable of this article is earnings management. From the research literatures, there are many methods to measure earnings management, among which the modified Jones model is the most widely used. Dechow et al. (1995) research shows that the modified Jones model is very effective for testing earnings management [15]. Therefore, this article also uses this to measure earnings management, as follows:

$$
\begin{gathered}
\text { TACC }_{i, t}=E_{i, t}-C F O_{i, t} \\
\frac{T{ }^{2} C_{i, t}}{T A_{i, t-1}}=\frac{\alpha_{0}}{T A_{i, t-1}}+\alpha_{1} * \frac{\Delta R E V_{i, t}-\Delta R E C_{i, t}}{T A_{i, t-1}}+\alpha_{2} * \frac{P P E_{i, t}}{T A_{i, t-1}}+\varepsilon_{i, t} \\
\frac{N D A C C_{i, t}}{T A_{i, t-1}}=\frac{\alpha_{0}}{T A_{i, t-1}}+\alpha_{1} * \frac{\Delta R E V_{i, t}-\Delta R E C_{i, t}}{T A_{i, t-1}}+\alpha_{2} * \frac{P P E_{i, t}}{T A_{i, t-1}} \\
\frac{D A C C_{i, t}}{T A_{i, t-1}}=\frac{T A C C_{i, t}}{T A_{i, t-1}}-\frac{N D A C C_{i, t}}{T A_{i, t-1}}
\end{gathered}
$$

The model is calculated as the total accruals profit (TACC) equal to the non-operating accruals $(N D A C C$ ) plus operating accruals (DACC). The total accruals are derived by formula (5), and the coefficients are regressed by formula (6), and the coefficients are substituted into formula (7) to obtain non-operating accruals. Finally, operational accruals are derived according to formula (8).

Where $T A C C_{i, t}$ for overall company $i$ accruals in the $t$ year; $E_{i, t}$ net profit for the first $t$ years of the company $i ; C F O_{i, t}$ means company is net cash flow of 
operating activities in $\mathrm{t}$ year; $T A_{i, t-1}$ is the total assets of the company $i$ in $t-1$ year ; the $R E V i$, t for the company $i$ s business income in the $t$ year minus that in the $t-1$ year; $\triangle R E V_{i, t} t$ for the company $i$ s account receivable in $t$ years minus that in the $t-1$ year; $P P E_{i, t}$ is the fixed asset value of the company $i ; N D A C C_{i, t}$ for the company $i$ s non-operating accruals in the $t$ year; $D A C C_{i, t}$ for the company $i$ s operating accruals in the $t$ year.

\subsection{Explainable Variable}

1) Cumulative negative abnormal return $\left(C A R_{i, t}^{\prime}\right)$

This paper uses event study method and uses market model to estimate abnormal return:

$$
r_{i, t^{\prime}}=\alpha_{i}+\beta_{i} R_{M t^{\prime}}+\varepsilon
$$

The abnormal return of stock $i$ on day $t A R_{i, t}$ is:

$$
A R_{i, t^{\prime \prime}}=r_{i, t^{\prime \prime}}-\alpha_{i}-\beta_{i} R_{M t^{\prime \prime}}
$$

The cumulative negative abnormal return of stock $i$ in $t^{\prime \prime} \in\left[t_{1}, t_{2}\right]$ is:

$$
C A R_{i}\left(t_{1}, t_{2}\right)=\sum_{t=t_{1}}^{t_{2}} A R_{i, t}
$$

Cumulative negative abnormal return is:

$$
C A R^{\prime}=\left\{\begin{array}{l}
0(C A R>0) \\
C A R(C A R<0)
\end{array}\right.
$$

where $r_{i, t^{\prime}}$ is the stock returns of company $i$ in $t$ day. $R_{i, t}$ is the GEM index's yield in $t$ day. We identify the lockup expiration dates based on information in the prospectus. We used a 80-day lockup duration as our estimation period (i.e., day -100 to day -20$)$. This means that abnormal returns at lockup expiration are compared to the normal returns when the shares were still locked. We observe the event period for fourteen days ( -7 days to +7 days) around the lockup expiration. This short-horizon approach prevents any potential confounding effects.

2) $V C s$ participation ( $V C$ )

We used a dummy variable for $V C$ involvement. Firms supported by $V C s$ were coded as 1 and as 0 otherwise.

3) VCs background

The background of venture capital institutions is set as dummy variables. The listed companies of venture capital institutions for state-owned shareholder background, the value 1 , otherwise 0 .

\section{4) $V C$ reputation.}

We conceptualize reputation as a record of past success perceived by stakeholders. As IPOs are typically the most successful outcomes for $V C$ investments, we measure reputation of $V C s$ by counting the number of new ventures that a $V C$ firm had taken public prior to the focal investment [7]. We reason that if investors believe that reputable VCs are more likely to fund companies that eventually go public, the number of new ventures taken public prior to the focal investment can be interpreted as a sign that the $V C s$ are capable of financing and 
guiding new ventures. We obtained the number of firms taken public by $V C s$ from the Venture data base and log-transformed the number to enhance normality.

\subsection{Control Variables}

The choice of control variables is integrated on the basis of previous studies to control the interpretation of relevant alternative theories.

1) The size of the company (Size) to measure the size of the company by the total assets of the company the year before its listing. Because the larger the company is, the financial report is more complex, which means that have more chance to earnings management; 2) the establishment period (Age) the longer the company exist, the more they tend to have rules to regulate the behavior of earnings management; 3) operating income growth rate (Growth), the growth stage companies to obtain larger future profits, shareholders and managers are more inclined to have earnings management behavior [9]; 4) IPO annual return on assets (ROA-IPO), IPO listed companies the performance in the first year will affect the decision of venture capital institutions judge; 5) underwriter reputation (TLU), the underwriter supervised the responsibility and obligation of the issuer, will exert influence on the issuer's financial report, and supervise the earnings management behavior. The higher the reputation of the Underwriters has, the more dynamic they will have to monitor. We calculate the underwriter reputation according to Carter and Manaster proposed "comprehensive index method"; 6) the audit agency reputation (CPA), if audit agencies can't identify or prevent the earnings management of listed companies, they are likely to face the risk of litigation, and their reputation will be damaged. The higher the reputation of audit institutions, the more dynamic they will have to monitor [9].

\section{Results}

In this paper, SPSS is adopted to verify the hypotheses. First of all, examining the whole sample in the degree of earnings management. Table 1 is the statistics of earnings management of Sample Firms:

It is seen from Table 1 of the statistical results, the number of positive earnings management companies in a sample of 330 GEM listed companies is 165 , accounted for $54.93 \%$, slightly higher than the non-positive earnings management companies, which means that the gem enterprises have positive earnings management behavior. Among them, the full sample of earnings management with an average of 0.0162 , positive earnings management average value is 0.1451 , non-positive earnings management average value is -0.1409 , which shows that, despite the existence of listed companies earnings management tendency, but the overall earnings management behavior is little.

For abnormal returns, this paper analyzes in different event windows, showing the results in Table 2. It can be found that before -8 days, although AR is negative, the magnitude is very small and not significant, so it can be considered 
Table 1. Descriptive statistics of earnings management.

\begin{tabular}{cccccccc}
\hline & Num & Pre & Mean & Median & Max & Min & SD \\
\hline $\begin{array}{c}\text { Positive earnings } \\
\text { management }\end{array}$ & 180 & $54.93 \%$ & 0.1451 & 0.0635 & 2.2205 & 0.00002 & 0.2343 \\
$\begin{array}{c}\text { Non-positive earnings } \\
\text { management }\end{array}$ & 150 & $45.07 \%$ & -0.1409 & -0.0955 & -0.0013 & -1.0432 & 0.1571 \\
All sample & 330 & $100 \%$ & 0.0162 & 0.0081 & 2.2205 & -1.0432 & 0.2479 \\
\hline
\end{tabular}

Table 2. Descriptive statistics of AR.

\begin{tabular}{cccc}
\hline \multirow{2}{*}{ Event day } & \multicolumn{3}{c}{ Abnormal return } \\
\cline { 2 - 4 } & Mean & Median & $\begin{array}{c}\text { Proportion of } \\
\text { negative values }\end{array}$ \\
\hline$-20--8$ & $-0.19 \%(-0.37)$ & $-0.50 \%$ & $51.49 \%$ \\
-7 & $-0.17 \%^{* *}(-2.56)$ & $-0.57 \%$ & $57.67 \%$ \\
-3 & $-0.45 \%^{* *}(4.31)$ & $-0.78 \%$ & $60.46 \%$ \\
-1 & $-0.40 \%^{* * *}(-4.09)$ & $-0.65 \%$ & $59.26 \%$ \\
0 & $-0.46 \%^{* * *}(-4.67)$ & $-0.60 \%$ & $58.76 \%$ \\
$1-3$ & $0.33 \%^{* *}(2.98)$ & $0.17 \%$ & $47.21 \%$ \\
$3-7$ & $-1.17 \%^{* *}(-2.26)$ & $-1.79 \%$ & $55.48 \%$ \\
$-20-20$ & $1.04 \%(-3.12)$ & $-0.30 \%$ & $44.58 \%$ \\
\hline
\end{tabular}

that, 7 days ago, the influence of lockup expiration on the stock return has no significant impact. From the beginning of -7 days, a single event occurred on the significant negative abnormal returns, abnormal return rate was above $-0.4 \%$ after -3 day, and reaches the minimum value of $-0.46 \%$ on the zeroth day, which means that stock abnormal return led to maximum on lockup day. And, -20 days to -8 days negative cumulative abnormal return is $50 \%$ or so, while on the -3 day to 0 day, negative abnormal return is close to $60 \%$, indicating that the date of event, event has general effect to abnormal return.

Table 3 presents the means, standard deviations, and correlations of our variables. To prevent distortion of the data due to multicollinearity, we examined the variance inflation factors (VIF) and found that none of them approached the suggested threshold of 10 [16].

Through descriptive statistical analysis, it can be found that the IPO enterprise shows a significant negative abnormal return during the lockup expiration. Next, this paper further tests the size of these abnormal returns. Table 4 is the $t$-test for the average abnormal return before and after the seven days. The results show that the negative return rate is related to the day of the lockup expiration, while the remaining time is not significant. Specifically, the estimated t-statistics shows that in this case, the possibility of abnormal return by accident is less than 0.1 percentage points $(t=-3.56, \mathrm{P}<0.001)$. In the sensitivity test, we examined a 
Table 3. Descriptive statistics and correlations.

\begin{tabular}{|c|c|c|c|c|c|c|c|c|c|c|c|c|c|}
\hline & Mean & $s d$ & $D A C C$ & $C A R^{\prime}$ & $V C$ & $V C_{b g}$ & $V C_{x p}$ & Size & Age & Growth & ROA_IPO & $T L U$ & $C P A$ \\
\hline$D A C C$ & 0.0162 & 0.2479 & 1 & & & & & & & & & & \\
\hline$C A R^{\prime}$ & 0.0437 & 0.0615 & 0.07 & 1 & & & & & & & & & \\
\hline$V C$ & 0.6567 & 0.4756 & -0.047 & $-0.125^{\star *}$ & 1 & & & & & & & & \\
\hline$V C_{b g}$ & 0.14 & 0.3476 & -0.042 & -0.044 & $0.292^{* * *}$ & 1 & & & & & & & \\
\hline$V C_{r p}$ & 0.0567 & 0.2316 & -0.02 & -0.008 & $0.177^{\star * *}$ & 0.026 & 1 & & & & & & \\
\hline Size & 4.9516 & 0.2139 & -0.022 & $-0.110^{*}$ & 0.073 & $0.129^{* *}$ & 0.075 & 1 & & & & & \\
\hline Age & 1.0676 & 0.1467 & 0.021 & -0.011 & -0.02 & 0.079 & -0.077 & -0.04 & 1 & & & & \\
\hline Growth & 0.2312 & 0.2611 & -0.043 & $-0.123^{* *}$ & -0.018 & 0.006 & 0.077 & $0.198^{\star * *}$ & $-0.166^{* * *}$ & 1 & & & \\
\hline ROA_IPO & 12.7778 & 4.3572 & -0.024 & -0.053 & $-0.103^{*}$ & $-0.124^{\star *}$ & 0.092 & 0.048 & 0.04 & $0.374^{\star * *}$ & 1 & & \\
\hline$T L U$ & 0.48 & 0.5004 & 0.003 & -0.023 & $0.133^{* *}$ & 0.093 & 0.053 & $0.142^{\star *}$ & -0.05 & -0.018 & -0.061 & 1 & \\
\hline$C P A$ & 0.48 & 0.5004 & $-0.114^{\star *}$ & $0.133^{* *}$ & 0.076 & -0.022 & $0.111^{*}$ & $0.103^{*}$ & -0.031 & 0.036 & 0.036 & 0.012 & 1 \\
\hline
\end{tabular}

$\dagger \mathrm{p}<0.10 ;{ }^{*} \mathrm{p}<0.05 ;{ }^{* *} \mathrm{p}<0.01 ;{ }^{* * *} \mathrm{p}<0.001$.

Table 4. Results of event study analysis for daily abnormal returns.

\begin{tabular}{|c|c|c|c|c|}
\hline Event day & $\begin{array}{l}\text { Abnormal } \\
\text { return }\end{array}$ & $t$-statistic & $\begin{array}{c}\text { Standardized } \\
\text { abnormal return }\end{array}$ & $t$-statistic \\
\hline-7 & 0.01397 & 0.593029 & 0.043982 & 0.873902 \\
\hline-6 & 0.00362 & 0.258940 & 0.27490 & 0.397859 \\
\hline-5 & -0.001006 & -0.498045 & -0.04389 & -0.569735 \\
\hline-4 & 0.00156 & 0.714690 & 0.01263 & 1.526748 \\
\hline-3 & 0.002559 & 0.792832 & 0.11247 & 1.227725 \\
\hline-2 & -0.004572 & -1.111311 & -0.095848 & -0.656361 \\
\hline-1 & -0.00356 & -1.22945 & -0.13727 & -1.57783 \\
\hline 0 & -0.00969 & $-3.56883^{\star * *}$ & -0.24587 & $-2.89821^{\star * *}$ \\
\hline 1 & -0.0013 & -0.54812 & -0.05757 & -0.82778 \\
\hline 2 & -0.001008 & -0.287137 & -0.031124 & -0.391294 \\
\hline 3 & -0.00087 & -0.28425 & 0.00424 & 0.047283 \\
\hline 4 & 0.00159 & 0.18940 & 0.00239 & 0.098459 \\
\hline 5 & 0.059304 & 0.26746 & 0.02954 & 0.039854 \\
\hline 6 & 0.094323 & 0.67842 & 0.05986 & 0.43875 \\
\hline 7 & 0.049879 & 0.04987 & 0.03854 & 0.03386 \\
\hline
\end{tabular}

$\mathrm{tp}<0.10 ;{ }^{*} \mathrm{p}<0.05 ;{ }^{* *} \mathrm{p}<0.01 ;{ }^{* *} \mathrm{p}<0.001$.

different time window by using $t-1, t 0$, and $t 1$ to calculate cumulative abnormal returns. We still observe a significant size of negative returns $(t=-2.92, \mathrm{p}<$ 
0.004). The results show strong negative returns at IPO lockup expiration $(t=$ $-2.89, \mathrm{p}<0.001)$. This result provides additional evidence that negative returns at lockup expiration do not occur by chance.

Table 5 is the result of stepwise regression. Model 1 includes all control variables. Some of the control variables were significant as a result. First, the scale of the enterprise $(\beta=-0.0208, \mathrm{P}<0.01)$ and auditor reputation $(\beta=-0.0139, \mathrm{P}$ $<0.01)$ associated with negative earnings management, enterprises set up years $(\beta=0.0084, \mathrm{P}<0.001)$ and the IPO annual return on assets $(\beta=0.0014, \mathrm{P}<0.01)$ was positively associated with earnings management. In addition, other control

Table 5. Results of the OLS regression estimating earnings management.

\begin{tabular}{|c|c|c|c|c|c|}
\hline & Model 1 & Model 2 & Model 3 & Model 4 & Model 5 \\
\hline \multicolumn{6}{|c|}{ Control variables } \\
\hline \multirow[b]{2}{*}{ Size } & $-0.0208^{\star *}$ & $-0.0190^{* *}$ & $-0.0184^{*}$ & -0.0165 & $-0.0176^{*}$ \\
\hline & $(-2.30)$ & $(-2.04)$ & $(-1.92)$ & $(-1.64)$ & $(-1.81)$ \\
\hline \multirow{2}{*}{ Age } & $0.0084^{* * *}$ & $0.0090^{* * *}$ & $0.0089^{* * *}$ & $0.0117^{\star * *}$ & $0.0101^{\star * *}$ \\
\hline & $(3.82)$ & $(3.75)$ & $(3.84)$ & $(4.00)$ & $(6.42)$ \\
\hline \multirow{2}{*}{ Growth } & -0.0065 & -0.0052 & -0.0046 & -0.0045 & -0.0051 \\
\hline & $(-1.11)$ & $(-0.83)$ & $(-0.69)$ & $(-0.70)$ & $(-0.85)$ \\
\hline \multirow{2}{*}{ ROA-IPO } & $0.0014^{\star *}$ & $0.0013^{*}$ & 0.0013 & 0.0012 & $0.0012^{*}$ \\
\hline & $(2.03)$ & $(1.77)$ & $(1.55)$ & $(1.46)$ & $(1.92)$ \\
\hline \multirow{2}{*}{ TLU } & -0.0122 & -0.0115 & -0.0111 & -0.0106 & -0.0105 \\
\hline & $(-1.52)$ & $(-1.33)$ & $(-1.23)$ & $(-1.11)$ & $(-1.31)$ \\
\hline$C P A$ & $-0.0139^{\star *}$ & $-0.0140^{* *}$ & $-0.0137^{\star \star}$ & $-0.0137^{\star *}$ & $-0.0130^{* *}$ \\
\hline \multicolumn{6}{|c|}{ Main effects } \\
\hline \multirow{2}{*}{$C A R$} & $(-2.31)$ & $(-2.12)$ & $(-2.02)$ & $(-2.04)$ & $(-2.02)$ \\
\hline & & $0.0400^{\star *}$ & $0.0399^{\star *}$ & $0.0366^{\star *}$ & $0.0436^{* * *}$ \\
\hline \multicolumn{6}{|l|}{$\begin{array}{l}\text { Interaction } \\
\text { effects }\end{array}$} \\
\hline$C A R \times V C$ & & & $\begin{array}{c}0.0237^{\star *} \\
(2.03)\end{array}$ & & \\
\hline \multirow[b]{2}{*}{$C A R \times V C-b g$} & & & & $-0.0637^{\star * *}$ & \\
\hline & & & & $(-2.85)$ & \\
\hline \multirow[b]{2}{*}{$C A R \times V C-r p$} & & & & & $-0.1814^{* * *}$ \\
\hline & & & & & $(3.29)$ \\
\hline \multirow{2}{*}{ cons } & $0.1411^{\star *}$ & $0.1278^{*}$ & $0.1269^{\star}$ & 0.1125 & 0.1177 \\
\hline & $(2.06)$ & $(1.79)$ & $(1.73)$ & $(1.48)$ & $(1.63)$ \\
\hline$R^{2}$ & 0.1495 & 0.1575 & 0.1604 & 0.1674 & 0.1630 \\
\hline F-statistic & 64.6449 & 22.0443 & 51.9412 & 65.0579 & 22.1929 \\
\hline
\end{tabular}

$\dagger \mathrm{p}<0.10 ;{ }^{*} \mathrm{p}<0.05 ;{ }^{* *} \mathrm{p}<0.01 ;{ }^{* * *} \mathrm{p}<0.001$ 
variables were not significant within the $10 \%$ range. Model 2 introduces the negative abnormal return variable. In the control variables, we find that the lockup expiration between the level of negative abnormal returns and earnings management has a significant positive coefficient $(\beta=0.04, \mathrm{P}<0.01)$, shows that there is a positive correlation between abnormal returns and negative earnings management. These results confirm that negative abnormal returns at lockup expiration are a good signal of earnings management behavior in IPOs. Thus, Hypothesis 1 is supported. Suppose 2 argues that firms with venture capital support firms have a stronger relationship between negative abnormal returns and earnings management. Model 3 introduce risk investment institutions as a negative regulator of variables between abnormal returns and earnings management, we find that when the VCs are involved in the IPO process, newly public firms tend to present higher levels of earnings management $(\beta=0.0237, \mathrm{p}<$ 0.01). Therefore, Hypothesis 2 also supports. Model 4 and model 5 describe the interaction between abnormal returns and the background and reputation of venture investment. In Hypothesis $3 \mathrm{a}$ and hypothesis $3 \mathrm{~b}$, we argued that the heterogeneity of venture capital will affect the relationship between abnormal returns and earnings management. The results show that the venture capital institutions with the background of state-owned and the higher reputation can reduce the relationship between abnormal returns and earnings management $(\beta=$ $-0.0637 /-0.1814, \mathrm{p}<0.001)$. Therefore, hypothesis $3 \mathrm{a}$ and Hypothesis $3 \mathrm{~b}$ are also supported.

\section{Conclusions}

IPO is regarded as the key to enterprise development and national economic growth and innovation [4], but there is limited research on the market performance of IPO lockup expiration in the existing literature [6]. This paper tries to fill the gap by studying the negative abnormal fluctuation of the stock price during the period of the lockup expiration. Based on the asymmetry theory and signal theory, this paper tests that at the IPO lockup expiration, whether negative abnormal returns at lockup expiration was a signal for earnings management, and explores what role the VCs play.

The results show that there is a negative market reaction at lockup expirations. However, not all firms experience negative abnormal returns. That is, the "good" enterprises at the lockup expiration, original shareholders are not eager to sell their shares, but for the long-term development of the enterprise they choose continue to hold. As a result, the market sees their commitment as a positive signal. On the contrary, eager to sell out, the market through this act can judge enterprise insiders may conceal some negative information, which might cause the stock price abnormal fluctuation appears negative. In addition, the study also found that indicate that $V C s$ play a significant detrimental role in earnings management. Evidence has been found that $V C s$ are responsible for the negative lockup effect, mainly the short-term investment horizon of VCs seeking to maximize their wealth. This paper also further researched by classified venture 
capital institutions, and found that venture capital institutions with state-owned background or high reputation weaken negative effect to the relationship between abnormal returns and earnings management, $V C s$ with state-owned and higher reputation play a monitoring a stronger effect, reducing the possibility of earnings management.

The research conclusion of this paper has important theoretical contributions and practical implications. First of all, research on the relationship among the risk investment mechanism, earnings management and market performance is less, so this study is a preliminary attempt, in the future, we can extend to investigate the companies' long-term performance when $V C s$ is involved and can study deeply on $V C s$ influence of the relationship between the earnings management and market performance; secondly, the conclusion of this paper has important implications for government departments and the management of the company: in recent years, risk investment institutions become more deeply involved in entrepreneurial development process, this research indicates that different types of $V C s$ attitude to earnings management is different. When the management of the company introduces long-term strategic investors, they should choose reputable venture capital institutions. In addition, negative abnormal return, as an important signal of earnings management, can help investors and regulatory authorities to identify and regulate the accounting adjustment behavior of enterprises, and maintain a good market environment.

\section{Limitations and Future Research Extensions}

This study is not without its limitations. First, although we found that the support of venture capital significantly improved the possibility of earnings management, we did not investigate the long-term performance of the firms under review. Second, the main motivation for our combination of control variables is to exclude other interpretations. However, some of our control variables are not significant. Third, we use a small sample of 330 IPO companies. This was helpful in preventing distortion from the dot-com bubble period. However, future research may wish to validate our research with larger time windows. Fourth, this study focuses on the role of VCs influencing negative stock price reaction at lockup expiration. However, it does not directly test either the magnitude of such a negative stock price reaction relative to the added value from their involvement in the pre-IPO period or the size of $V C$ cash-outs after the lockup expiration.

In conclusion, we explained how lockup expiration increases the potential for mismatches between incentives for internal and external investors. We found that a negative price decline following lockup expiration can be an effective signal for such a misalignment. We hope that this article will shed light on the transition phase of new enterprises into mature enterprises and provide important insights that can be used to promote entrepreneurship and improve social welfare. 


\section{References}

[1] Ducharme, L.L., Malatesta, P.H. and Sefcik, S.E. (2001) Earnings Management: IPO Valuation and Subsequent Performance. Journal of Accounting, Auditing \& Finance, 16, 369-396. https://doi.org/10.1177/0148558X0101600409

[2] Jenkinson, T. and Ljungqvist, A. (1996) Going Public: The Theory and Evidence on How Companies Raise Equity Finance. OUP Catalogue, 65, 619-620.

[3] Connelly, B.L., Certo, S.T., Ireland, R.D. and Reutzel, C.R. (2015) Signaling Theory: A Review and Assessment. Journal of Management Official Journal of the Southern Management Association, 37, 39-67.

[4] Teoh, S.H., Wong, T.J. and Rao, G.R. (1998) Are Accrual during Initial Public Offerings Opportunistic. Review of Accounting Studies, 3, 175-208. https://doi.org/10.1023/A:1009688619882

[5] Healy, P.M. and Wahlen, J.M. (1999) A Review of the Earnings Management Literature and Its Implications for Standard Setting. Social Science Electronic Publishing, 13, 365-383.

[6] Richardson Pettit, R. (1972) Dividend Announcements, Security Performance, and Capital Market Efficiency. Journal of Finance, 27, 993-1007. https://doi.org/10.1111/j.1540-6261.1972.tb03018.x

[7] Hsu, D.H. (2006) Venture Capitalists and Cooperative Start-Up Commercialization Strategy. Management Science, 52, 204-219. https://doi.org/10.1287/mnsc.1050.0480

[8] Jain, B.A., Jayaraman, N. and Kini, O. (2008) The Path-to-Profitability of Internet IPO Firms. Journal of Business Venturing, 23, 165-194. https://doi.org/10.1016/j.jbusvent.2007.02.004

[9] Morsfield, S.G. and Tan, C.E.L. (2006) Do Venture Capitalists Influence the Decision to Manage Earnings in Initial Public Offerings? Accounting Review, 81, 11191150. https://doi.org/10.2308/accr.2006.81.5.1119

[10] Allcock, D. (2009) Executive Incentive Schemes in Initial Public Offerings: The Effects of Multiple-Agency Conflicts and Corporate Governance. Journal of Management, 36, 235-238.

[11] Miller, D. and Sardais, C. (2011) Angel Agents: Agency Theory Reconsidered. Academy of Management Executive, 25, 6-13. https://doi.org/10.5465/AMP.2011.61020798

[12] Park, H.D. and Steensma, H.K. (2013) The Selection and Nurturing Effects of Corporate Investors on New Venture Innovativeness. Strategic Entrepreneurship Journal, 7, 311-330. https://doi.org/10.1002/sej.1165

[13] Dalziel, T., White, R.E. and Arthurs, J.D. (2011) Principal Costs in Initial Public Offerings. Journal of Management Studies, 48, 1346-1364. https://doi.org/10.1111/j.1467-6486.2010.01005.x

[14] Chahine, S., Arthurs, J.D., Filatotchev, I. and Hoskisson, R.E. (2012) The Effects of Venture Capital Syndicate Diversity on Earnings Management and Performance of IPOs in the US and UK: An Institutional Perspective. Journal of Corporate Finance, 18, 179-192. https://doi.org/10.1016/j.jcorpfin.2011.11.007

[15] Dechow, P.M., Sloan, R.G. and Sweeney, A.P. (1995) Detecting Earnings Management. Accounting Review, 70, 193-225.

[16] Arthurs, J.D., Hoskisson, R.E., Busenitz, L.W. and Johnson, R.A. (2008) Managerial Agents Watching Other Agents: Multiple Agency Conflicts Regarding Underpricing in IPO Firms. Academy of Management Journal, 51, 277-294.

https://doi.org/10.5465/AMJ.2008.31767256 
Submit or recommend next manuscript to SCIRP and we will provide best service for you:

Accepting pre-submission inquiries through Email, Facebook, LinkedIn, Twitter, etc. A wide selection of journals (inclusive of 9 subjects, more than 200 journals)

Providing 24-hour high-quality service

User-friendly online submission system

Fair and swift peer-review system

Efficient typesetting and proofreading procedure

Display of the result of downloads and visits, as well as the number of cited articles Maximum dissemination of your research work

Submit your manuscript at: http://papersubmission.scirp.org/

Or contact me@scirp.org 